\title{
Potensi Lestari Perikanan Tangkap sebagai Basis Pengelolaan Sumberdaya di Kabupaten Pangandaran
}

\author{
Pigoselpi Anas, Iis Jubaedah, Dinno Sudinno \\ Jurusan Penyuluhan Perikanan - Sekolah Tinggi Perikanan \\ Jalan Cikaret Nomor 2 Bogor, Jawa Barat \\ Diterima: 18 Mei 2016;: disetujui: 07 Juli 2016
}

[Potential For Sustainable Fishing Resources Management Base in the District of Pangandaran]

\begin{abstract}
Abstrak
Kajian potensi lestari perikanan tangkap dilakukan pada bulan Agustus - Oktober 2015 di kabupaten Pangandaran Jawa Barat. Tujuan penelitian ini untuk mengetahui beberapa aspek penangkapan meliputi jumlah alat tangkap optimal, Catch per unit effort ( CPUE ), potensi maksimum lestari (MSY) dan Total Allowable Catch ( TAC) serta Mengetahui tingkat pemanfaatan sumberdaya ikan di perairan Kabupaten Pangandaran. Metode yang digunakan pada penelitian ini adalah metode survei. Hasil penelitian menunjukkan bahwa Potensi lestari perikanan Tangkap di Perairan Pangandaran Provinsi Jawa Barat menggunakan formula model Schaefer diperoleh hasil sebagai berikut Jumlah alat tangkap optimal (Emsy) $=2006,4$ unit, pada saat ini jumlah alat tangkap yang ada telah melebihi jumlah optimalnya.. Hasil tangkapan lestari $(\mathrm{Cmsy})=2415,4$ ton ,dan jumlah tangkapan ikan yang diperbolehkan (Total Allowable Catch = TAC) sebesar 1932 ton sedangkan tingkat pemanfaatan sumberdaya ikan berdasarkan hasil tangkapan dan alat tangkap di perairan Kabupaten Pangandaran telah mencapai tangkapan lestari.
\end{abstract}

Kata kunci: kabupaten pangandaran, lestari, potensi maksimum

\begin{abstract}
Study of the potential for sustainable capture fisheries conducted in August - October 2015 in the district of Pangandaran, West Java. The purpose of this study to know some aspects of the arrests include optimal number of fishing gear, Catch per unit effort (CPUE), the potential maximum sustainable (MSY) and the Total Allowable Catch (TAC) and know the level of utilization of fish resources in the waters of the District Pangandaran. The method used in this study is a survey method. The results showed that the potential of sustainable fishery catch in the waters of Pangandaran, West Java Province using the model formula Schaefer obtained the following results optimal amount of fishing gear $($ Emsy $)=2006.4$ units, at this time the amount of fishing gear that there are in excess of the optimal .. Results sustainable catches $(\mathrm{Cmsy})=2415.4$ tons, and the amount of allowable fish catches $($ TAC $=$ Total allowable Catch) amounted to 1932 tonnes, while the level of utilization of fish resources based on catches and fishing gear in waters Pangandaran Regency has achieved sustainable catches
\end{abstract}

Keyword: district pangandaran, maximum potential, sustainable.

\section{PENDAHULUAN}

Potensi dari sumberdaya perikanan merupakan modal dasar pembangunan nasional yang dapat memberikan sumber devisa bagi Negara dari sektor non migas

$\triangle$ Penulis korespondensi Alamat surel: pigoselpianas@yahoo.com melalui peningkatan ekspor. Disamping itu, perikanan sebagai sumberdaya, juga rentan terhadap pemanfaatan oleh manusia secara berlebihan Perairan Pangandaran mempunyai potensi sumberdaya hayati 
laut yang cukup besar, namun, dalam perkembangan kegiatan penangkapan ikan terdapat beberapa isu diantaranya adanya gejala penangkapan ikan yang berlebih (overfishing), Penangkapan yang berlebih menguras sumberdaya dan berdampak pada hilangnya sumber mata pencaharian nelayan (Monintja, 2000). Pemerintah melalui Kementerian Kelautan dan Perikanan (KKP) mendapat mandat dalam mengatur perikanan tangkap untuk mencegah terjadinya penangkapan berlebih, sehingga mencegah terkurasnya sumberdaya dan atau memaksimalkan keuntungan jangka panjang dari nelayan (Daduk, 2009).

Peningkatan kegiatan intensitas penangkapan ikan akan dapat memberikan dampak positif dan negatif. Dampak positif adalah adanya suatu peningkatan produksi yang pada akhirnya memberikan keuntungan, sedangkan dampak negatif adalah apabila intensitas penangkapan yang dilakukan tidak seimbang dengan potensi sumberdaya ikan. Hal ini akan mengakibatkan pengurangan stok dan pada akhirnya akan terjadi penurunan produksi hasil tangkapan (Hulaifi, 2011). Dengan demikian suatu pengelolaan sumberdaya perikanan menjadi sangat kompleks dengan berbagai macam permasalahan yang memerlukan penyelesaian sangat hati-hati dan berdimensi jangka panjang atau strategis.

Penelitian ini bertujuan untuk mencapai hal-hal berikut:

1. Mengetahui sebeberapa jauh aspek penangkapan yang meliputi jumlah alat tangkap optimal, Catch per unit effort atau CPUE, potensi maksimum lestari atau MSY dan Total Allowable Catch atau TAC (Bengen, 2000).

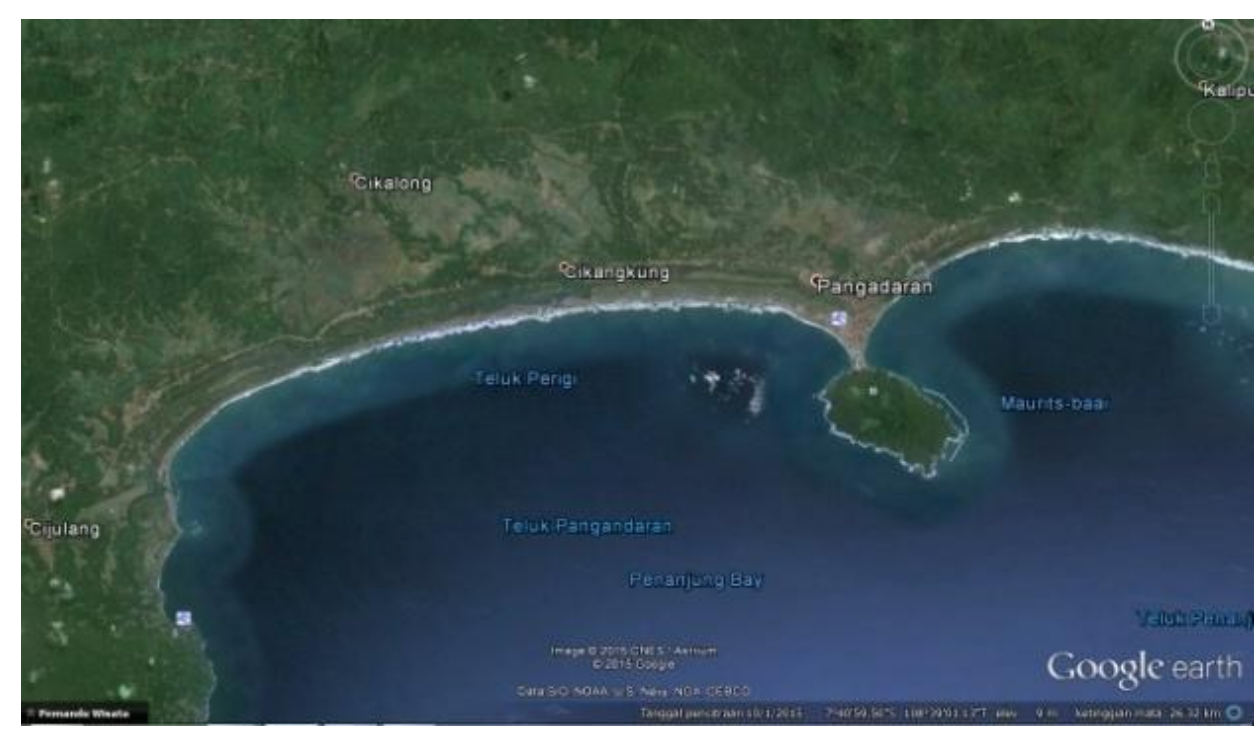

Gambar 1. Lokasi penelitian di Kabupaten Pangandaran Jawa Barat 
2. Mengetahui tingkatan pemanfaatan sumberdaya komoditi ikan di perairan Kabupaten Pangandaran

\section{BAHAN DAN METODE}

Penelitian telah dilaksanakan di Kabupaten Pangandaran Jawa Barat pada bulan Agustus - Oktober 2015.

Metode yang digunakan pada penelitian ini adalah metode survei. Metode survei merupakan metode penelitian dimana unit dan aspek yang dikaji banyak serta jumlah populasi cukup besar (Nazir, 1983). Data yang telah dikumpulkan mencakup data primer dan data sekunder. Metode pengambilan data yaitu dengan cara melakukan pengamatan langsung di lapangan dan wawancara.

Data primer diperoleh dengan melakukan pengamatan langsung dan wawancara dengan para pelaku kegiatan penangkapan ikan (stakeholders). Data sekunder diperoleh dari instansi terkait seperti Dinas Perikanan dan Kelautan Kabupaten Pangandaran, Unit Pelaksana Teknis Daerah PPI Pangandaran, KUD dan TPI. Data tersebut meliputi :

1) Volume kegiatan produksi perikanan di Kabupaten Pangandaran 13 tahun terakhir

2) Jumlah para nelayan di Kabupaten Pangandaran
3) Jumlah perahu dan kapal yang beroperasi di daerah wilayah perairan pangandaran

4) Jumlah dan jenis alat tangkap yang beroperasi di perairan Pangandaran

5) Keadaan umum perairan Pangandaran, letak geografis, topografi, luas wilayah, keadaan iklim, musim dan cerah hujan.

Metode analisis yang digunakan adalah sebagai berikut (Ayodhya, 1981):

\section{Hasil tangkap per-upaya penangkapan} (CPUE).

Analisis CPUE dihitung berdasarkan total hasil tangkapan dari suatu alat tangkap dengan jumlah total upaya penangkapan (effort) dalam satuan unit. CPUE dihitung dengan formula sebagai berikut :

$$
C P U E_{i t}=\frac{\text { CATCH }_{i t}}{E F F O R T_{i t}}
$$

\section{Keterangan:}

CPUE

$=$ Catch per unit effort alat tangkap ke $i$ waktu ke $t$ $\mathrm{CATCH}_{\text {it }}=$

Hasil tangkapan alat tangkap ke $i$ waktu ke $t$ EFORT $_{\text {it }}$

$=$ Upaya penangkapan alat tangkap ke $i$ waktu ke $t$

\section{Potensi Maksimum Lestari ( MSY)}

Upaya tangkap optimum $\left(f_{\text {opt }}\right)$ dan MSY dapat dihitung dengan cara menggunakan persamaan Schaefer. Upaya optimum $\left(f_{\text {opt }}\right)$ dihitung dengan menggunakan persamaan $f_{\text {opt }}=\frac{a}{2 b}$. MSY dihitung dengan menggunakan persamaan $M S Y=\frac{a^{2}}{4 b}$, 
dimana a adalah intersept dan $b$ adalah slope pada persamaan regresi linear

3. Jumlah tangkapan yang diperbolehkan $($ Total Allowable Catch $=$ TAC).

Jumlah tangkap ikan yang diperbolehkan (TAC) dihitung sebagai TAC $=80 \%$ MSY .

\section{HASIL DAN PEMBAHASAN}

\section{Kondisi umum}

Secara umum Pangandaran beriklim tropis dengan dua musim yaitu musim kemarau (musim timur) dan musim hujan (musim barat) dengan curah hujan rata-rata per tahun sekitar $1.647 \mathrm{~mm}$, kelembaban udara antara 85-89\% dengan suhu berkisar antara $20-30^{\circ} \mathrm{c}$. Musim timur dan musim barat secara langsung akan mempengaruhi musim penangkapan ikan di area perairan Pangandaran. Musim timur terjadi pada bulan Mei sampai Oktober, dimana saat terjadi musim ini laut tidak berombak besar dan perairan dalam keadaan tenang, sehingga operasi penangkapan ikan di laut tidak terganggu. Musim barat terjadi pada bulan November sampai April, dimana saat terjadi musim ini laut sedang dalam keadaan ombak besar, sehingga operasi penangkapan ikan-ikan di lautan menjadi terganggu.

\section{Daerah Penangkapan Ikan}

Sebagian besar armada penangkapan ikan yang digunakan oleh nelayan Pangandaran yaitu perahu motor tempel yang menggunakan cadik. Daerah penangkapan ikan tempat beroperasinya nelayan Pangandaran juga terdapat di sekitarTeluk Pangandaran, perairan Parigi, Karapyak, perairan Nusakambangan, dan Cilacap. Waktu yang dibutuhkan oleh nelayan untuk sampai atau tiba ke daerah

Tabel 1. Jumlah alat tangkap ikan menurut jenisnya tahun 2000 -2012

\begin{tabular}{cccccccc}
\hline Tahun & Dogol & $\begin{array}{c}\text { Pukat } \\
\text { Pantai }\end{array}$ & Gillnet & Bagan & Rawai & $\begin{array}{c}\text { Tramel } \\
\text { net }\end{array}$ & Jumlah \\
\hline 2000 & 187 & 16 & 1032 & - & 195 & 433 & 1863 \\
2001 & 187 & 18 & 921 & - & 213 & 433 & 1772 \\
2002 & 187 & 18 & 921 & - & 213 & 433 & 1772 \\
2003 & 141 & 37 & 843 & - & 84 & 83 & 1188 \\
2004 & 158 & 12 & 737 & - & 85 & 94 & 1086 \\
2005 & 158 & 12 & 737 & - & 85 & 94 & 1086 \\
2006 & 97 & 14 & 475 & - & 50 & 52 & 688 \\
2007 & 97 & 14 & 1648 & - & 85 & 52 & 1896 \\
2008 & 193 & - & 1221 & - & 96 & 147 & 1657 \\
2009 & 201 & 27 & $\mathbf{2 ~ 3 9 5}$ & 20 & 469 & $\mathbf{3 0 3}$ & 3415 \\
2010 & 201 & 27 & $\mathbf{2 ~ 3 9 5}$ & 20 & 469 & $\mathbf{3 0 3}$ & 3415 \\
2011 & 201 & 27 & $\mathbf{2 ~ 3 9 5}$ & 20 & 469 & $\mathbf{3 0 3}$ & 3415 \\
2012 & 201 & 27 & $\mathbf{1 ~ 8 6 5}$ & 20 & 469 & $\mathbf{3 0 3}$ & 2885 \\
\hline
\end{tabular}


penangkapan ikan yang dituju berkisar antara 40-60 menit dari fishing base. Penentuan daerah penangkapan ikan dilakukan dengan tetap mengandalkan pengalaman, kebiasaan dan ciri-ciri yang terdapat di perairan. Nelayan tidak menggunakan alat bantu apapun untuk menentukan daerah penangkapan ikan. Alat tangkap yang dapat beroperasi di Pangandaran diantaranya yaitu pancing rawai, jaring insang (gillnet), jaring tiga lapis (trammel net), pukat pantai, dan jaring jogol / dogol (Dinas Kelautan dan Perikanan Kabupaten Pangandaran 2013).

Hasil tangkapan yang diproduksi oleh alat tangkap yang beroperasi di perairan Pangandaran dalam kurun waktu tiga belas tahun terakhir mengalami fluktuasi, hal tersebut dilihat pada Tabel 2.

\section{Potensi Lestari Stok Ikan}

Potensi lestari stok Ikan merupakan angka yang menunjukkan jumlah Ikan yang diperkenankan untuk ditangkap sehingga tetap terjaga kelestariannya (Subani \& Barus, 1989). Dalam analisa potensi juga dapat diketahui berapa jumlah upaya (effort) yang diperkenankan sehingga stok dapat terjaga kelestariannya. Pada penelitian ini digunakan model surplus produksi yaitu model Schaefer. Dari hasil tangkap Ikan di perairan sector Kabupaten Pangandaran, jumlah alat tangkap dan jumlah tangkapan per unit (CPUE) disajikan pada Tabel 3.

Dari tabel 3 terlihat bahwa hasil tangkap dari tahun ke tahun cenderung menurun. Hal ini disebabkan antara lain karena jumlah unit alat tangkap dari tahun ke tahun terlihat semakin meningkat.

Tabel 2. Produksi hasil tangkapan ikan tahun 2000-2012

\begin{tabular}{cc}
\hline Tahun & Produksi ( Ton ) \\
\hline 2000 & 1736,34 \\
2001 & 2529,80 \\
2002 & 2168,20 \\
2003 & 2599,61 \\
2004 & 1871,04 \\
2005 & 1205,68 \\
2006 & 1605,61 \\
2007 & 1665,52 \\
2008 & 1997,11 \\
2009 & 1231,88 \\
2010 & 441,77 \\
2011 & 759,24 \\
2012 & 2219,91 \\
\hline
\end{tabular}


Hubungan CPUE dengan upaya adalah linier tetapi bersifat negatif, dalam arti setiap penambahan upaya penangkapan akan menurunkan nilai CPUE (Onolawe dkk, 2011). Menurut Berachi (2003 dalam Diani dkk, 2012): besaran dari CPUE dapat digunakan sebagai indikator tingkat efisiensi tehnik dari upaya penangkapan leffort, dengan kata lain CPUE yang lebih tinggi akan mencerminkan tingkat efisiensi penggunaan effort yang jauh lebih baik semakin meningkatnya penangkapan yang dilakukan ternyata hasil tangkapan per unit usaha penangkapan (CPUE) yang nantinya diperoleh semakin kecil (Rosana \& Prasita, 2015). Analisis regresi dilakukan guna mengetahui kondisi trend penurunan hasil tangkapan setiap alat (CPUE) mempunyai seberapa jauh pengaruh penambahan jumlah tangkap terhadap hasil tangkap per unit. Demikian pula dapat ditentukan dengan hasil tangkapan jika telah terjadi perubahan jumlah alat. Dalam analisis regresi, model persamaan Schaefer untuk sumberdaya Ikan di perairan Pangandaran yaitu: $Y=-0,0006 x+2,4077$. Dengan aplikasi persamaan di atas diperoleh grafik sebagaimana ilustrasi berikut: sebagai variabel bebas (independent variabel) yaitu jumlah upaya penangkapan (effort: E) dalam hal ini jumlah alat tangkap, sedangkan untuk variabel tak bebasnya (dependent variabel) yaitu hasil tangkap tiap alat tangkap (catch per unit effort $=$ CPUE). Dari hasil analisis yang telah dilakukan nilai dari R2 atau koefisien

Tabel 3. Jumlah Tangkapan Per Unit (CPUE) di lokasi penelitian

\begin{tabular}{cccc}
\hline Tahun & Produksi (Ton) & Effort (unit) & CPUE (Ton) \\
\hline 2000 & 1736,34 & 1863 & 0,932 \\
2001 & 2529,80 & 1772 & 1,427 \\
2002 & 2168,20 & 1772 & 1,223 \\
2003 & 2599,61 & 1188 & 2,188 \\
2004 & 1871,04 & 1086 & 1,722 \\
2005 & 1205,68 & 1086 & 1,110 \\
2006 & 1605,61 & 688 & 2,333 \\
2007 & 1665,52 & 1896 & 0,878 \\
2008 & 1997,11 & 1657 & 1,205 \\
2009 & 1231,88 & 3415 & 0,360 \\
2010 & 441,77 & 3415 & 0,129 \\
2011 & 759,24 & 3415 & 0,222 \\
2012 & 2219,91 & 2885 & 0,769 \\
\hline
\end{tabular}


determinasi) sebesar $80,8 \%$, hal ini berarti variabel jumlah alat tangkap dapat mempengaruhi variabel CPUE sebesar $80,8 \%$, sedangkan sisanya dipengaruhi oleh variabel lain. Dari kurva regresi di atas dapat dijelaskan bahwa semakin banyak jumlah alat tangkap, maka semakin berkurang jumlah hasil tangkap Ikan pada setiap satu alat tangkap (CPUE). Kurva tersebut menunjukkan eksploitasi yang terjadi di areal perairan Pangandaran dan sekitarnya terhadap poduksi Ikan telah berlebihan (over fishing). Apabila keadaan ini terus dibiarkan, maka akibatnya stok Ikan yang ada di perairan Pangandaran dan sekitarnya akan semakin berkurang, bahkan pada saatnya akan kehabisan stok. Oleh karena itu sangat diperlukan suatu pengelolaan secara konservatif terhadap sumber daya Ikan (Deden, 2009). Semakin meningkatnya upaya penangkapan maka hasil tangkapan per unit upayanya akan semakin kecil. Menurut trend CPUE yang juga naik merupakan gambaran bahwa pada tingkat eksploitasi dari sumberdaya ikan dapat dikatakan masih pada tahapan yang berkembang (Elis \& Nurul, 2013). Trend CPUE yang mendatar merupakan gambaran bahwa tingkat eksploitasi sumberdaya ikan yang sudah mendekati kejenuhan upaya, sedangkan trend CPUE yang menurun merupakan indikasi bahwa tingkat eksploitasi sumberdaya ikan apabila terus dibiarkan akan mengarah kepada suatu keadaan yang disebut 'overfishing' atau bahkan telah 'overfished' (Rochmah dkk, 2013).

\section{Maximum Sustainable Yield (MSY)}

Dari hasil analisis regresi didapat konstanta $\mathrm{a}=2,4077$ dan koefisien regresi $\mathrm{b}=-0,0006$. Dengan juga menggunakan formula model Schaefer. Jumlah alat tangkap optimal $($ Emsy) $=2006,4$ unit Hasil tangkapan lestari $($ Cmsy $)=2415,4$ ton Model Schaefer adalah satu metode pendugaan yang mempunyai keuntungan yaitu sederhana dan tidak memerlukan banyak data, tetapi dapat memberikan informasi awal yang diperlukan dalam pengelolaan sumber daya. Persamaan model Schaefer secara umum dapat dilihat pada Gambar 2.

Sumbu Y merupakan jumlah hasil tangkap/unit (CPUE) Ikan dan sumbu X adalah jumlah alat tangkap . Dari Grafik Maximum Sustanable Yield (MSY) di atas diketahui bahwa titik A merupakan titik dimana terjadi MSY. Pada kondisi tersebut terjadi pemanfaatan maximum dengan mempertahankan kelestarian sumber daya Ikan di Pangandaran. MSY diperoleh bila jumlah alat adalah 2006,4 unit. Atikah (2013) menyampakan bahwa nilai MSY di Pangandaran sebesar 1582 ton. Tingkat pemanfaatan potensi sumberdaya Ikan diketahui tangkapan lestarinya 2415,4 ton. 


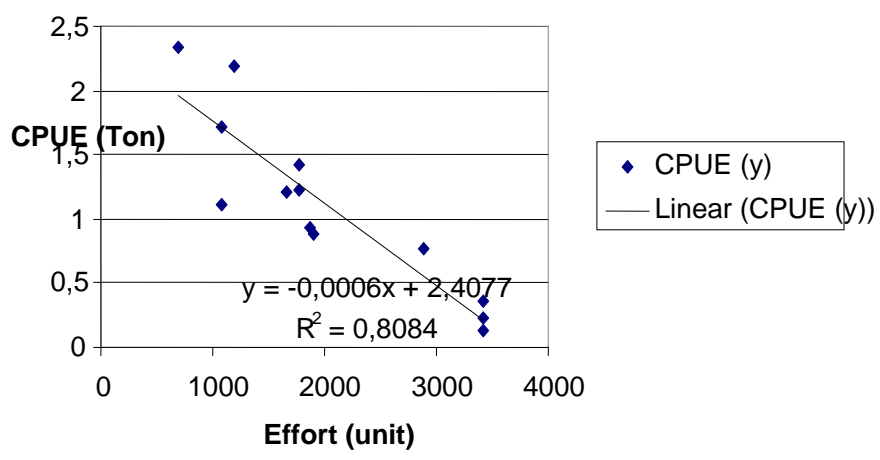

Gambar 2. Hubungan antara jumlah alat tangkap dengan hasil tangkapan per unit

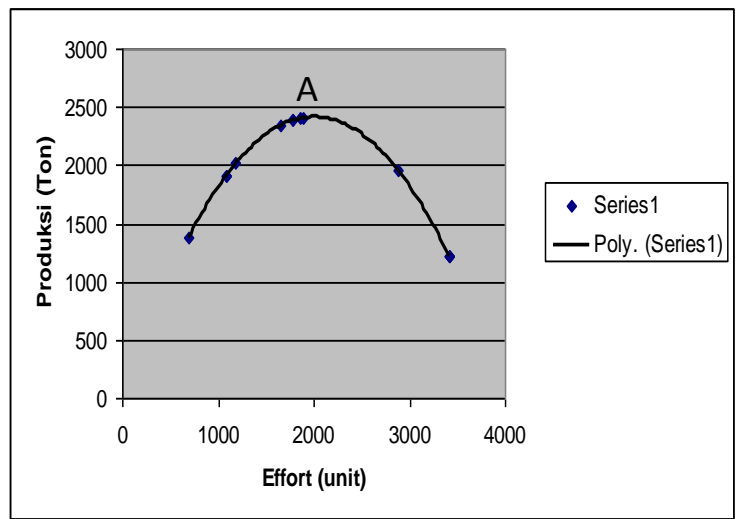

Gambar 3. Grafik maximum sustanable yield (MSY)

Tabel 4.Tingkat pemanfaatan potensi sumber daya ikan berdasar hasil tangkapan

\begin{tabular}{ccc}
\hline Tahun & Produksi ( Ton ) & Tingkat Pemanfaatan $(\%)$ \\
\hline 2000 & 1736,34 & 71,8 \\
2001 & 2529,80 & 104,7 \\
2002 & 2168,20 & 89,7 \\
2003 & 2599,61 & 107,6 \\
2004 & 1871,04 & 77,4 \\
2005 & 1205,68 & 49,9 \\
2006 & 1605,61 & 66,4 \\
2007 & 1665,52 & 68,9 \\
2008 & 1997,11 & 82,6 \\
2009 & 1231,88 & 51 \\
2010 & 441,77 & 18,2 \\
2011 & 759,24 & 31,4 \\
2012 & 2219,91 & 91,9 \\
\hline
\end{tabular}




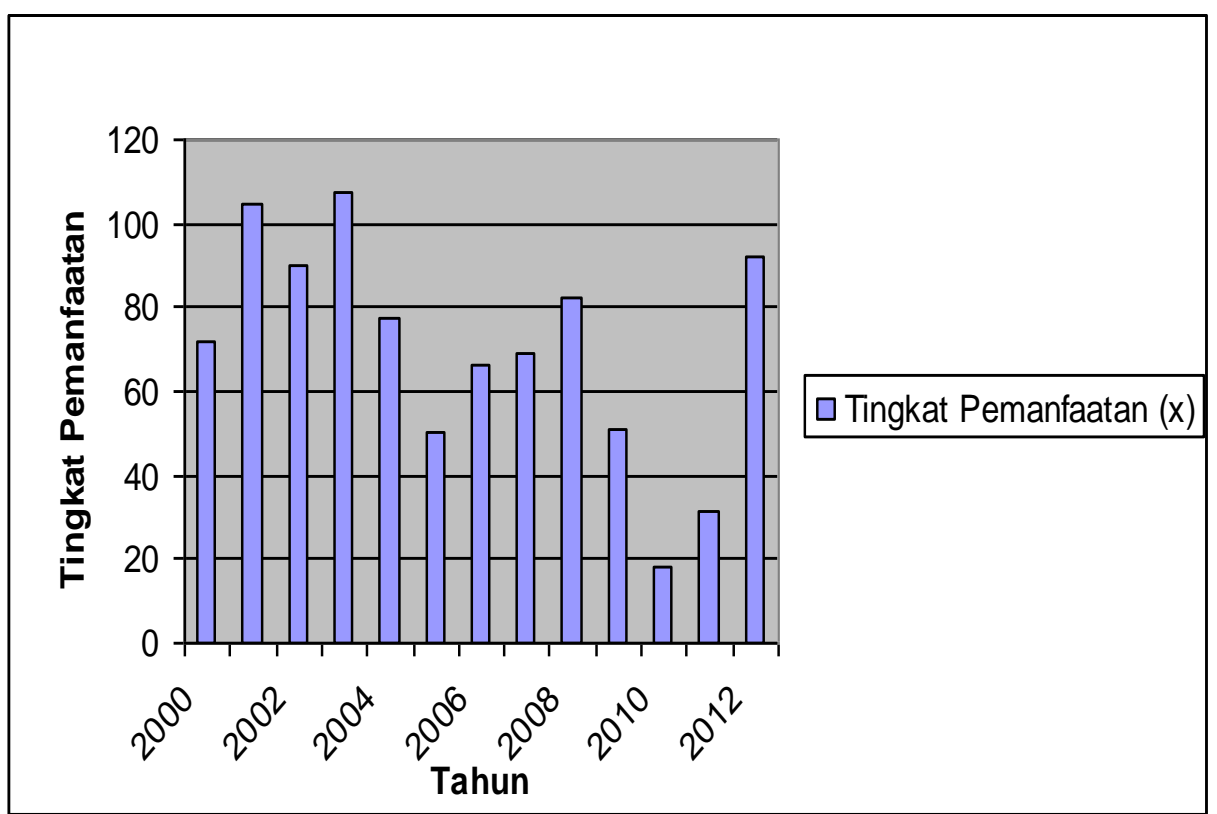

Gambar 4.Tingkat pemanfaatan potensi sumber daya ikan berdasar hasil tangkapan

Tabel 5. Tingkat pemanfaatan potensi sumber daya ikan berdasarkan alat tangkap

\begin{tabular}{ccc}
\hline Tahun & Jumlah Alat (Unit) & Tingkat Pemanfaatan (\%) \\
\hline 2000 & 1863 & 92,8 \\
2001 & 1772 & 88,3 \\
2002 & 1772 & 88,3 \\
2003 & 1188 & 59,2 \\
2004 & 1086 & 54,1 \\
2005 & 1086 & 54,1 \\
2006 & 688 & 34,2 \\
2007 & 1896 & 94,5 \\
2008 & 1657 & 82,6 \\
2009 & 3415 & 170,2 \\
2010 & 3415 & 170,2 \\
2011 & 3415 & 170,2 \\
2012 & 2885 & 143,8 \\
\hline
\end{tabular}

Pemanfaatan potensi sumberdaya ikan atas dasar prinsip kehati-hatian (Gulland, 1982), karenanya potensi ikan yang diperbolehkan untuk ditangkap (Total Allowable Catch = TAC) sebesar 1932 ton. Dari ilustrasi tersebut diketahui bahwa semenjak tahun 2001 pemanfaatan telah mencapai tangkapan lestarinya, sehingga pengelolaan perlu dilakukan terhadap kondisi tersebut melalui pembatasan jumlah hasil tangkapan (Sahono, 2012). Pada kondisi penelitian terjadi penurunan CPUE seperti pada Tabel 3. 
- Pemanfaatan sumber daya ikan yang tidak dikendalikan menyebabkan semakin menurunnya hasil tangkapan (Hendrik, 2011), penelitian ini mencatat pada tahun 2010 yang hanya 441,77 ton sementara alat tangkapnya bertambah 3415,4 unit.

Pada ilustrasi tersebut pengelolaan perlu dilakukan dengan suatu pembatasan jumlah alat tangkap hingga pada jumlah 2006,4 unit, yang perlu dilakukan untuk kembali melestarikan sumber daya Ikan di perairan Pangandaran. Untuk mengatasi gejala tangkap lebih maka sangat penting dilakukan upaya pengelolaan mengingat sifat sumberdaya ikan meskipun dapat diperbaharui (renewable), namun perlu kehati-hatian dalam pemanfaatannya untuk menjamin keberlanjutan yang baik dalam jumlah maupun kemampuannya untuk regenerasi (Budiman, 2006). Sebagai tahap awal dalam kegiatan pengelolaan adalah mengetahui dinamika hasil tangkapan nelayan dan mengetahui pada tingkat pemanfaatannya, khususnya terhadap suatu hasil tangkapan (BPPI, 1996). populasi ikan laut merupakan sumberdaya alam yang akan dapat diperbaharui namun memiliki kemungkinan untuk dapat punah, apabila pemanfaatannya secara berlebihan. Dalam usaha memanfaatkan sumberdaya perikanan tersebut, diharapkan akan tetap memperhatikan semua aspek kelestarian sumberdaya yang dieksploitasi. Untuk itu diperlukan suatu manajemen ekploitasi yang tepat (Hertini \& Gusriani, 2013)

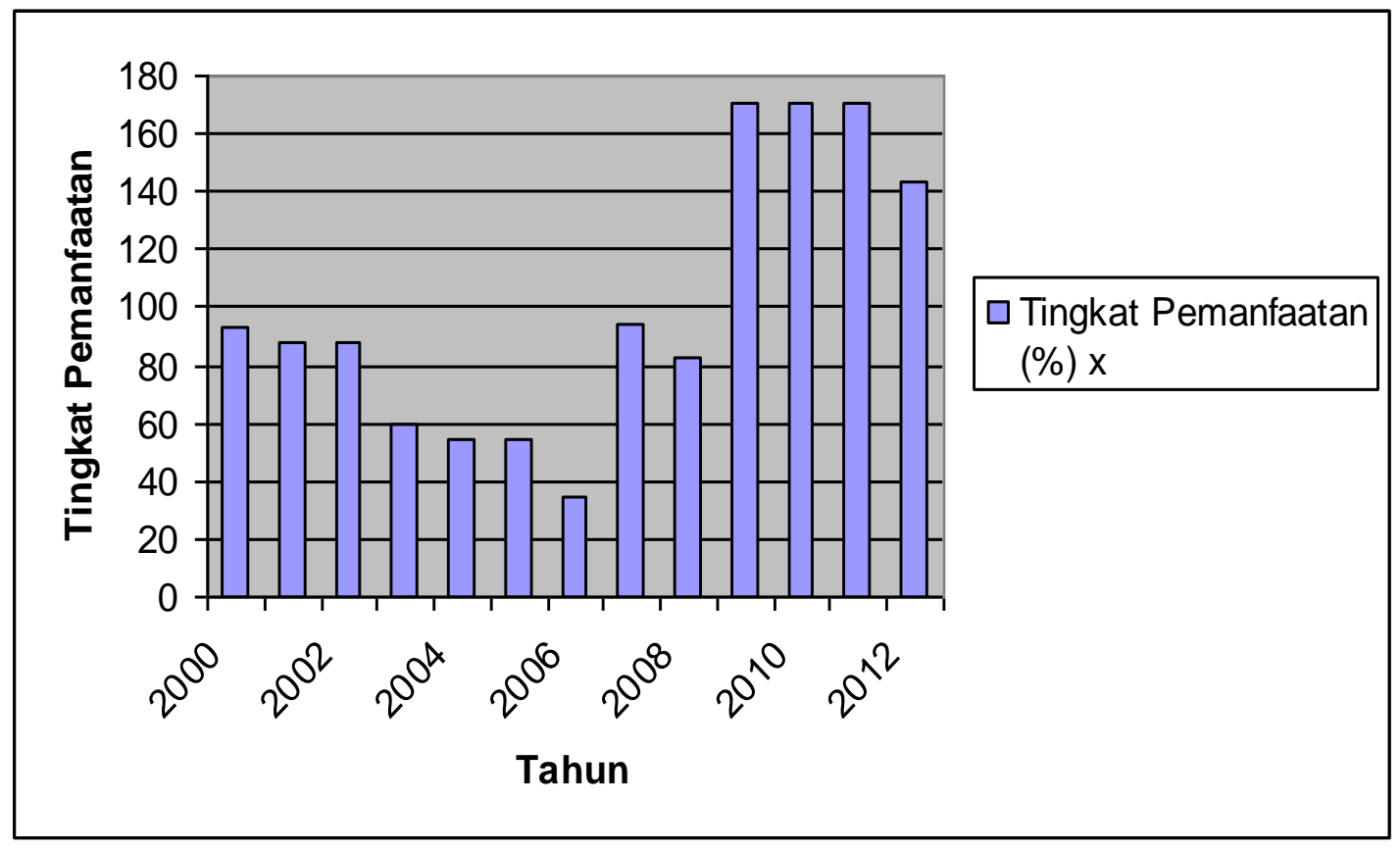

Gambar 5. Grafik tingkat pemanfaatan potensi sumber daya ikan berdasarkan alat tangkap 


\section{SIMPULAN DAN SARAN}

\section{Simpulan}

1. Potensi lestari perikanan Tangkap di Perairan Pangandaran Provinsi Jawa Barat menggunakan formula model Schaefer diperoleh hasil sebagai berikut Jumlah alat tangkap optimal (Emsy) = 2006,4 unit, pada saat ini jumlah alat tangkap yang ada telah melebihi jumlah optimalnya.. Hasil tangkapan lestari $($ Cmsy $)=2415,4$ ton ,dan jumlah tangkapan ikan yang diperbolehkan $($ Total Allowable Catch $=$ TAC) sebesar 1932 ton

2. Tingkat pemanfaatan sumberdaya ikan berdasarkan hasil tangkapan dan alat tangkap di perairan Kabupaten Pangandaran telah mencapai tangkapan lestari

\section{Saran}

Pengelolaan perlu dilakukan dengan pembatasan jumlah alat tangkap hingga pada jumlah 2006, empat unit, yang perlu dilakukan untuk kembali melestarikan sumber daya ikan di perairan Kabupaten Pangandaran.

\section{DAFTAR PUSTAKA}

Atikah N. 2013. analisis potensi lestari perikanan tangkap di kawasan Pangandaran. Fakultas perikanan dan ilmu kelautan dari Universitas
Padjadjaran. Jurnal Akuatika Vol IV (2) september 2013

Ayodhya AU 1981. Metode Penangkapan Ikan. Bogor: Yayasan Dewi Sri.

Bengen DG. 2000. Pedoman pelatihan untuk pelatih pengelolaan wilayah pesisir terpadu. IPB Bogor.

Budiman. 2006. Analisis sebaran ikan demersal sebagai basis pengelolaan sumber daya pesisir di Kabupaten Kendal. Tesis. Program Pasca Sarjana Universitas Diponegoro Semarang.

BPPI. 1996. Alternatif usaha penangkapan ikan jaring pantai (pukat tarik / arad) bagi nelayan skala kecil. BPPI Semarang.

Daduk Setyohadi. Studi potensii dan dinamika stok ikan lemuru (Sardinella lemuru) di Selat BaliI serta alternatif penangkapannya. Fakultas Perikanan dan Ilmu Kelautan, Universitas Brawijaya Jurnal Perikanan (J. Fish. Sci.) XI (1): 78-86 ISSN: 0853-6384

Deden HA. 2009. Kajian prospek pengembangan perikanan tangkap pasca tsunami di PPI Pangandaran, Jawa Barat. Institut Pertanian Bogor

Elis H, dan Nurul G. 2013. Maximum sustainanable yield (MSY) pada perikanan dengan struktur preypredator. Jurusan Matematika FMIPA Universitas Padjadjaran Prosiding Seminar Nasional Sains dan Teknologi Nuklir PTNBR BATAN Bandung, 4 Juli 2013

Gulland. 1982. Manual of methods for fish stock assesment part I. Fish Population Analysis. FAO Rome

Hendrik. 2010. Potensi sumberdaya perikanan dan tingkat eksploitasi 
(Kajian terhadap Danau Pulau Besar dan Danau Bawah Zamrud Kabupaten Siak Provinsi Riau) Fakultas Perikanan dan Ilmu Kelautan pada Universitas Riau Pekanbaru. Jurnal Perikanan dan Kelautan 15 (2): 121-131

Hulaifi. 2011. Pendugaan potensi sumberdaya perikanan laut dan tingkat keragaan ekonomi penangkapan ikan (Kasus di TPI Sendang Biru Kabupaten Malang) Jurnal Matematika, Sains, dan Teknologi, Vol. 12 (2): 113-126

Monintja DR. 2000. Pemanfaatan pesisir dan laut untuk kegiatan perikanan tangkap: Prosiding penelitian untuk pelatih pengelolaan wilayah pesisir terpadu. Pusat Kegiatan Sumberdaya Pesisir dan Laut. Institut Pertanian Bogor.

Nazir M. 1983. Metode penelitian. Bahan Kuliah. Jakarta: Ghalia Indonesia.

Onolawe PS, Fauziyah, Fitri A. 2011. Analisis potensi lestari sumberdaya perikanan tuna longline di Kabupaten Cilacap, Jawa Tengah. Program Studi Ilmu Kelautan FMIPA, Universitas Sriwijaya. Maspari Journal 03: 24-29

Rochmah TC, Sutrisno A , Bambang Y. 2013. Potensi lestari sumberdaya ikan demersal (analisis hasil tangkapan cantrang yang didaratkan di TPI Wedung Demak) Prosiding Seminar Nasional Pengelolaan Sumberdaya Alam dan Lingkungan 2013

Rosana N dan Prasita VD. 2015. Potensi dan tingkat pemanfaatan ikan sebagai dasar pengembangan sektor perikanan di Selatan Jawa Timur. Fakultas Teknik dan Ilmu Kelautan Universitas Hang Tuah. Jurnal Kelautan Vol 8 (2). Oktober 2015 ISSN: 1907-9931

Sahono B. 2012. Pengelolaan perikanan tangkap komoditas udang secara berkelanjutan di Kabupaten Cilacap Tesis. Program Pasca Sarjana Universitas Indonesia

Subani W, dan HP Barus. 1989. Alat penangkap ikan laut dan udang di perairan indonesia. Jurnal Penelitian Perikanan Laut No. 50 Tahun 1988/1989. Edisi Khusus. Jakarta : BPPL, BPPP. Departemen Pertanian. 